\title{
Intermédialités
}

Histoire et théorie des arts, des lettres et des techniques

Intermediality

History and Theory of the Arts, Literature and Technologies

\section{Readings at the Intersection: Social Ecologies in Critical Texts}

\section{Claire M. Holdsworth}

Numéro 30-31, automne 2017, printemps 2018

cartographier (l'intermédialité)

mapping (intermediality)

URI : https://id.erudit.org/iderudit/1049946ar

DOI : https://doi.org/10.7202/1049946ar

Aller au sommaire du numéro

Éditeur(s)

Revue intermédialités (Presses de l’Université de Montréal)

ISSN

1920-3136 (numérique)

Découvrir la revue

Citer cet article

Holdsworth, C. M. (2017). Readings at the Intersection: Social Ecologies in

Critical Texts. Intermédialités / Intermediality, (30-31).

https://doi.org/10.7202/1049946ar
Résumé de l'article

À partir d'extraits de compte-rendus de la revue éphémère Readings qu'ont éditée les artistes Annabel Nicolson et Paul Burwell en 1977, cet article examine le lien entre les collectifs d'artistes The London Musicians' Collective et la London Film-makers' Co-operative, tous deux basés à la même adresse entre 1977 et 1988. Il s'agit de montrer la façon dont les textes, en tant qu'ils prolongent les pratiques artistiques, engrangent une pensée critique de la performance, mais également différentes cultures contemporaines. Des revues comme Readings fournissent des outils idoines pour cartographier la complexité des écologies sociales et les croisements entre les disciplines. 


\title{
Readings at the Intersection: Social Ecologies in Critical Texts
}

\author{
Claire M. HOLDSWORTH
}

\section{INTRODUCTION-INVISIBLE ECOLOGIES}

rt magazines and other forms of ephemeral critical writing often inscribe histories that are missed by more conventional narrated accounts. As these kinds of publications contain multiple texts by many authors, they have an immediacy of address that is rooted in and responds to the "current" context in which they are produced. By considering the ways artistic practices are inscribed in and through critical writings, this article compares extracts from the first issue of the artistrun magazine Readings, published in February 1977. This short-lived reviews magazine reveals connections between two artist-led groups, neighbours who inhabited a shared address at 42 Gloucester Avenue in the Camden area of North London. The London Film-makers' Co-operative (hereafter the Film Co-op) ${ }^{\mathrm{I}}$ has been the subject of study and interest in recent years, whereas the London Musicians' Collective (LMC) is less discussed in art histories. The LMC was a collectively used rehearsal space and venue, and the improvised music-making that took place there was different from the activities pursued by members of the Film Co-op next door who administered a distribution office, a cinema, and facilities for shooting, editing, processing and printing film and video. When they negotiated the terms of their joint tenancy, the LMC was newly formed and in the process of determining its constitution, while the Film Co-op had already been established for ten years (and was coming to the end of an itinerant phase). Despite their differences, both organizations shared this address for just over a decade-from 1977 until 1988-

\footnotetext{
I Events marking the $50^{\text {th }}$ anniversary of the founding of the London Film-makers' Co-op took place throughout 2016 at the British Film Institute (BFI), Tate galleries, and LUX London, amongst others. See Mark Webber (ed.), Shoot, Shoot, Shoot: The First Decade of the London Film-Makers' Co-Operative, 1966-67, London, LUX, 2016.
} 
entering a period of stability during which both collectives, in different but significant ways, transformed the artistic, social, political, and critical landscape in London.

Readings was a small bi-monthly publication (see Fig. I and 2), which was partially funded through the Film Co-op's advertising budget and ran only three issues in February, April, and the summer of 1977. This simply designed series of black-and-white booklets provides a vignette of a specific moment, precisely when these organizations moved to Gloucester Avenue. Each edition's pages contain writings about performances at the LMC, the Film Co-op, and other venues. The pieces were written by artists working across these spaces, though it is important to stress that collaborations between the Film Co-op and the LMC were few and that the two organizations tended to keep one another at a distance. This article does not survey each group nor their memberships in detail; instead, it uses the first issue of Readings as a map, a key to artistic geographies and subcultures that extend beyond Gloucester Avenue. This publication provides a means of locating in-common (interesse $)^{2}$ perceptions in hindsight, mapping subjects sometimes lost in studies that concentrate on a single artist, discipline, or organization.
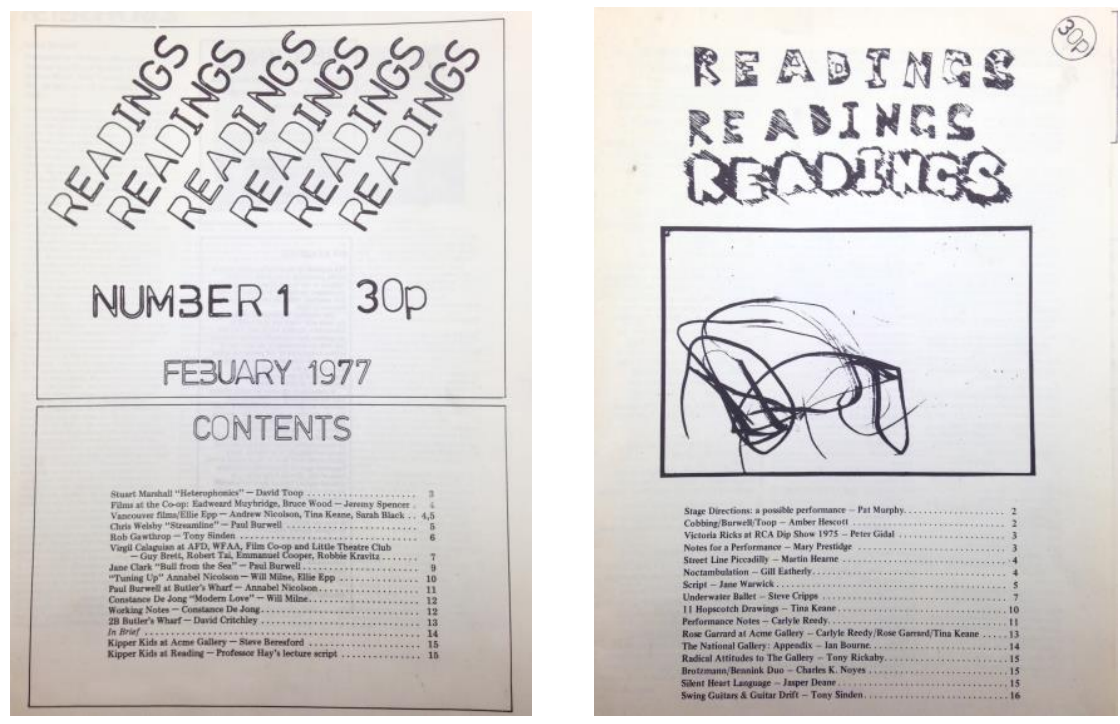

Fig. I-2. Front covers Readings No. I and No.3 (published February and Summer 1977). Published with the permission of Annabel Nicolson

${ }^{2}$ Henk Oosterling and Ewa Płonowska Ziarek(eds.), Intermedialities: Philosophy, Arts, Politics, Lanham, Lexington Books, 2010. 
At 42 Gloucester Avenue performances and conversations did occasionally extend from one space into the other. This was largely initiated by personal friendships such as that of Readings' editors Annabel Nicolson and Paul Burwell. It was through their close relationship and administrative roles in these organizations that the LMC and the Film Co-op came to share the same address. Burwell was a founding member of the LMC, acting as its secretary for the first two years ${ }^{3}$ and Nicolson worked as cinema programmer at the Film Co-op in 1974 and between 1976 and 1977 when Readings was published. ${ }^{4}$ As well as organizational roles, these editors pursued unique, boundary-blurring artistic practices. Burwell used percussive improvisation to create immersive live-action performances that transformed the spaces in which they took place. During the 1980s, he built sculptural site-specific instruments and performances as a member of Bow Gamelan Ensemble (with Anne Bean and Richard Wilson). Nicolson created innovative protofilmic live-actions and was part of the informal coalition of filmmakers who performed under the banner Filmaktion in the early 1970s.5 Both Burwell and Nicolson were engaged exponents of art who pushed music and film into new spaces, creating new ecologies that were both critical and physical. ${ }^{6}$

The texts collated in Readings by Burwell and Nicolson, reveal connections that, to use Susan Star and Anselm Strauss' phrasing, are both visible and invisible in nature ${ }^{7}$ - raising issues that affect historical accounts, including this study, which rely on materials from this period that are now held in archives and special collections. ${ }^{8}$

3 Filmmaker and Co-op member Guy Sherwin was also a contact during the LMC's move to Gloucester Avenue.

4 Nicolson went on to become a founding member of Circles Women's Film and Distribution (1979), which merged with Cinema of Women to become Cinenova in 1991. For a general overview, see: http://www.luxonline.org.uk/histories/1970-1979/circles.html (accessed 28 February 20I8); http://www.cinenova.org/ (accessed 28 February 2018).

5 Filmaktion included other Co-op members Gill Eatherley, Malcolm LeGrice, and William Raban.

${ }^{6}$ Gene Youngblood, "The Artist as Ecologist," in Expanded Cinema, New York, Dutton, 1970, p. 346-364,

7 Susan Star and Anselm Strauss, "Layers of Silence, Arenas of Voice: the Ecology of Visible and Invisible Work," Computer Supported Cooperative Work, vol. 8, nos. I-2, March 1999, p.9-30,

${ }^{8}$ British Artists' Film and Video Study Collection, Central Saint Martins Museum, University of the Arts London (UAL), www.studycollection.org.uk (accessed 4 January 20I8); London Musicians' Collective Archive, UAL Archives and Special Collections Centre, London College of Communication, University of the Arts London. See Sound Traces - The LMC 
As a hybridized concept stretching across the "boundaries of all media," intermedia is significant for reflecting upon how the histories of these groups are written since it "links many forms of media conceptually, and requires us to consider them [...] in terms of human effects" 9 -and it is human effects in the form of reviews that are collated in Readings.

\section{“INTO THE LABORATORY"10}

Historian David Curtis, who was also a member of the Film Co-op, has discussed how the "ideals of the creative laboratory" spurred the establishment of this and other creative spaces in London in the late 1960s, such as the Drury Lane and Robert Street Arts Labs (where Curtis was also cinema programmer between 1967 and 1970$)^{12}$ or the television workshop TVX initiated by Underground journalist and filmmaker John "Hoppy" Hopkins in the I970s, before he established the Fantasy Factory video lab with Sue Hall in the $1980{ }^{\mathrm{I}}{ }^{3}$ At that time, collective and cooperative models enabled artists with an interest in varied media to access expensive technologies, hard-to-find equipment, and the facilities required to work them. As "laboratories" these spaces used scientific as opposed to artistic models-aiming to pioneer, discover, experiment-and echoed the drive of the Sixties as a time of great technological leaps forward, particularly for audio-visual media, with the first portable "Portapak" video system released by Sony in 1968.

Archive, curated by D. Toop, online exhibition, http://soundtraces.crisap.org/ (accessed 4 January 2018).

9 Definition of "Intermedia," in Steven Jones (ed.), Encyclopedia of New Media: An Essential Reference to Communication and Technology, Thousand Oaks, California, SAGE Publications, 2002, p. 246.

10 Greil Marcus, Invisible Republic: Bob Dylan's Basement Tapes, London, Picador, 1998, p. xv.

"I David Curtis, A History of Artists' Film and Video in Britain, London, British Film Institute, 2006, p. 26.

${ }^{12}$ The Drury Lane Arts Lab showed experimental film, poetry, performance, and theatre and was founded by theatre director Jim Haynes in 1967. For a general presentation, see: http://www.luxonline.org.uk/history/1960-I969/drury_lane_arts_lab.html_ (accessed 28 February 2018).

13 Joe Boyd and Val Wilmer, "Obituary: John 'Hoppy' Hopkins," The Guardian, I5 February, 2015, https://www.theguardian.com/artanddesign/2015/feb/I5/john-hoppyhopkins (accessed I7 March 2018). 
READINGS AT THE INTERSECTION: SOCIAL ECOLOGIES IN CRITICAL TEXTS

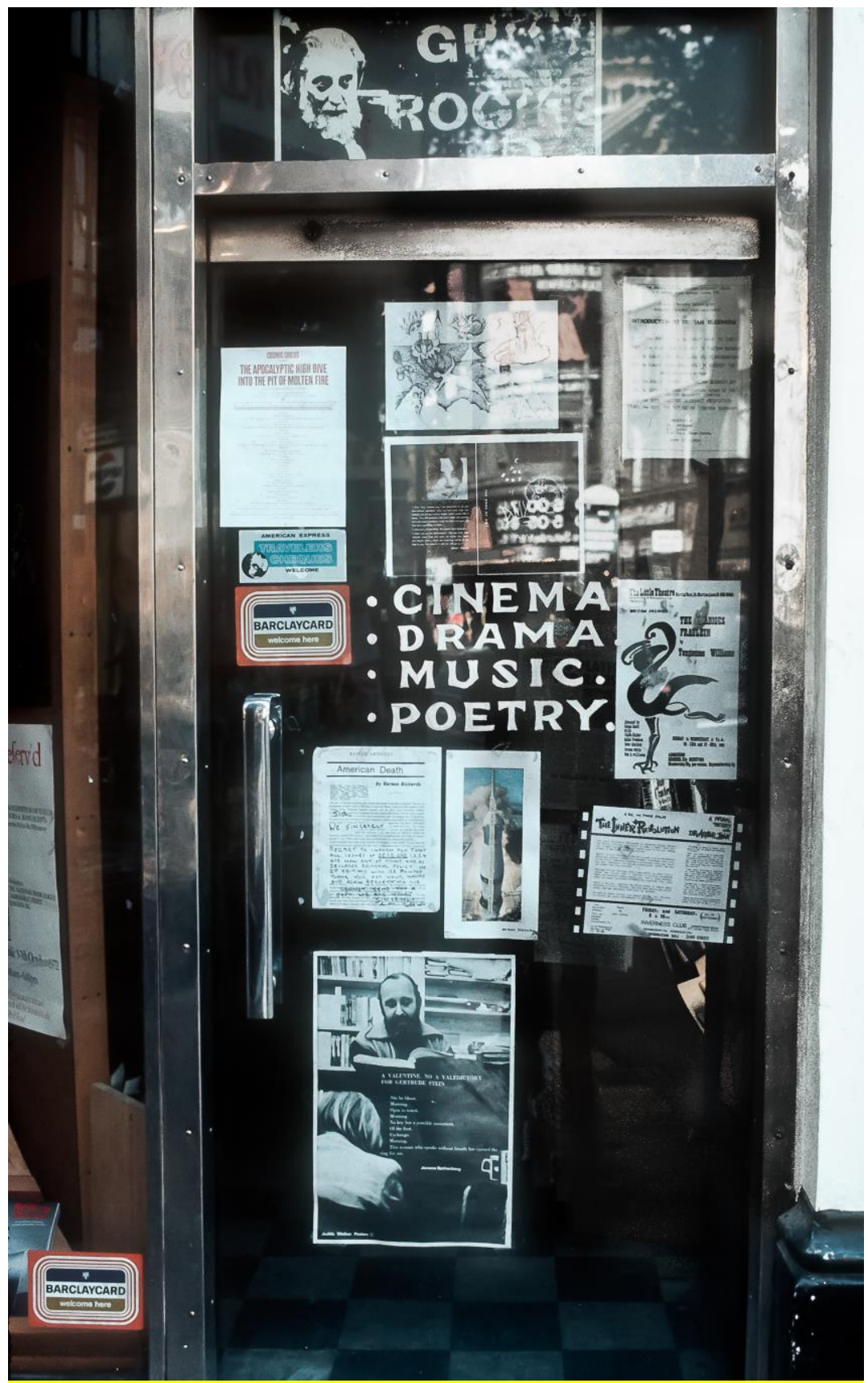

Fig. 3. Better Books Bookshop, Charing Cross Road, London (March 1972). Photos @ Richard Friedman. Published with the permission of Richard Friedman. 


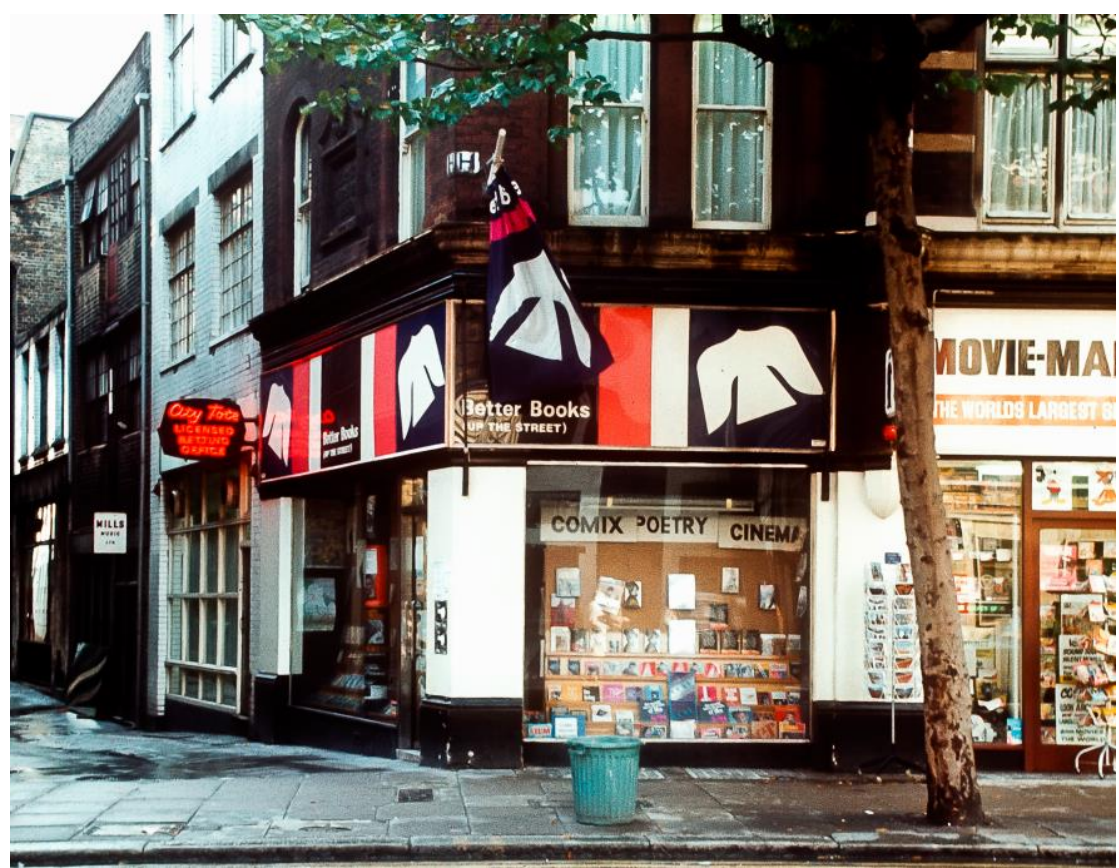

Fig. 4. Better Books Bookshop, Charing Cross Road, London (March 1972). Photos $\odot$ Richard Friedman. Published with the permission of Richard Friedman. to "new" multidisciplinary approaches such as those made in these labs. The term described pursuits that traverse multiple fields-for example, "drama, music, and poetry," as was written on the door of the Better Books bookshop where the Film Coop was founded in 1966 (see Fig. 3 and 4). In many ways, the Film Co-op reflects the diverse spirit of the Intermedia Film Co-op or Intermedia Society in Vancouver (1969-1972), and ideas explored in studies by composer Dick Higgins and filmmaker Jonas Mekas of the New York Film-makers' Cooperative. ${ }^{\mathrm{I}}$ Although pertinent to this period, definitions of intermedia are not necessarily directly connected to specific practices at the Film Co-op (and at the LMC). An early definition by the Intermedia Systems Corporation describes it as "the simultaneous use of various media to create a total environmental experience for the audience. Meaning is communicated not by

${ }^{14}$ The London Film Co-op had close ties with the NY Film Co-op. Mekas sent a telegram when the London Co-op was founded and he was instrumental to adding US works, by artists such as Kenneth Anger, Stan Brakhage, Maya Deren, Michael Snow, to their distribution catalogue. 
coding ideas into abstract literary language, but by creating an emotionally real experience." is Differing from this description, many film and video practitioners discussed their experimental ideas (and those of others) in writings. For instance, the Film Co-op published the magazine $C I N I M^{16}$ in 1969 as well as Readings ten years later. ${ }^{17}$

The LMC was founded in 1977 following a meeting of the National Musicians' Collective at the Birmingham Arts Lab. Free improvisation developed as both a technique and a genre during the 1950 and 1960 , influenced by jazz, groups such as the Musicians' Cooperative, the Scratch Orchestra, AMM, ${ }^{18}$ and others, performing improvised pieces in which musicians played varied instruments, and/or objects attached to contact microphones. In Burwell's 1986 personal history of the LMC-published in the catalogue accompanying Light Years: A Twenty Year Celebration of the London Film-makers' Co-operative19 - he outlines that "completely separately, but involving the same group of people [as the LMC], the magazine MUSICS came into existence, edited by a collective (anyone who was willing to do the work)." ${ }^{20}$ This magazine was published between 1975 and $1979^{2 \mathrm{I}}$ and further to editing Readings, Nicolson was an editorial contributor to the MUSICS collective alongside other second generation improvisers like Burwell, Evan Parker, and Clive Bell. ${ }^{22}$ Burwell points out that if "no one was writing about the music, reviewing it, developing critical ideas, publicising events and so on, then the musicians had to do it themselves." ${ }^{23}$ Despite the very stark creative differences between the LMC and the

Is "Intermedia Systems Corporation," in Youngblood, 1970, p. 348.

${ }^{16}$ Kathryn Siegel, "Rebirth of the 6th art in Cinim, 1966-69," Il Intermedia: The Moving Form of Film: Exploring Intermediality as a Historiographic Method, conference, University of Reading (UK), November 6-8, 2017.

${ }^{17}$ A later example is Undercut: The Magazine of the London Film Co-op, published from 198I until I990.

${ }^{18}$ AMM (1965/66 onwards), Eddie Prévost, Keith Rowe, Lou Gare, Lawrence Sheaff, and Cornelius Cardew of the Scratch Orchestra (with other members over the years).

19 Paul Burwell "London Musicians Collective: A Personal History," in Light Years: A Twenty Year Celebration of the London Film-makers' Co-operative, festival catalogue, London, LFMC, 1986, p. 27-29.

${ }^{20}$ Ibid., p. 28.

${ }^{21}$ The 23-issue back-catalogue of MUSICS has been republished as a facsimile edition. MUSICS: A Magazine of Improvised Music and Art 1975-1979, Ecstatic Peace Library, 2016.

${ }_{22}$ Clive Bell, "History of the LMC," Variant, no. 8, Summer 1999, http://www.variant.org.uk/8texts/Clive_Bell.html (accessed 5 January 20r8).

${ }^{23}$ Burwell, 1986, p. 28. 
Film Co-op, members from both coalitions not only wrote critical texts, they also edited (and sometimes even typeset) the publications in which these writings were published.

\section{“OUTWORN STRUCTURES”}

Up a decaying metal staircase, above a laundry, lurked a pair of large, grimy open spaces, formerly canteens for British Rail workers. ${ }^{24}$

When they moved to Gloucester Avenue, the LMC and the Film Co-op divided what had once been a larger space-a former canteen and entertainment social club for British Rail workers, located opposite The Engineer pub in Camden. This conversion echoed other changes in this area, including that of the Roundhouse, a former railway turning shed transformed into an influential music venue. ${ }^{25}$ In 1976 more anarchic and nihilistic ideas were transforming the ideals of Sixties lab-culture, heralded by the emergence of punk music at that moment, with its epicentre in pubs and squatted spaces around Camden, although the Film Co-op and the LMC were not straightforwardly part of this wider cultural zeitgeist. ${ }^{26}$ Each organization was relatively self-contained and tended to keep mainstream culture and even one another at a distance, evidenced by the fact that soon after the groups had agreed the terms of their joint tenancy, LMC members built a breeze-block wall to divide the space. ${ }^{27}$ In this context, collective support structures provided a means of inhabiting, administering, and reclaiming empty industrial spaces in post-war London as arts labs, co-ops, workshops, and collectives rerouted the infrastructures of industry to serve new and more egalitarian modes of cultural production. ${ }^{28}$

24 Clive Bell, "Bell Labs: Improv Will Eat Itself," The Wire, June 1993, www.thewire.co.uk/in-writing/columns/bell-labs_improv-will-eat-itself_ (accessed I3 December 2017).

${ }^{25}$ Angel Lambo, "Roundhouse and I97os Youth Culture," The Roundhouse: Celebrating so Years, https://5o.roundhouse.org.uk/content-items/roundhouse-youth-culture (accessed I8 December 2017).

${ }^{26}$ Simon Reynolds, Retromania: Pop Culture's Addiction to Its Own Past, London, Faber, 2011.

${ }^{27}$ The LMC had around a third of the space, the canteen of the former social club, while the Film Co-op occupied the entertainment facilities.

${ }^{28}$ The Arts Council GB administered funding to both the LMC and Film Co-op (from separate departments/units). 
Both the Film Co-op and the LMC were political and socially alert, adopting organized models of production. Trumpeter Gerry Gold indicates the alternative socialist politics underlying improvised music, aligning social restructuring with radical artistic experiment. Gold called for a "co-operative organisation" in recognition of the fact that a new improvised, "living music is in process of piercing the outworn structures of existing forms.” 29 The politics of these organizational structures echoed those of the artworks they fostered (and vice versa), questioning and dissecting hegemonies and the cultural tropes of society, to re-form them anew.

Readings was a "bi-monthly publication devoted to writings on (reviews of) recent work that has no existence in time beyond its own structural duration-dance, performance, music, film." ${ }^{\circ}$ As a magazine containing reviews and accounts it traces locations beyond Gloucester Avenue and Camden. The listings and the "In Brief" sections describe events all over London and the first issue includes a short history of the venue $2 \mathrm{~B}$ Butlers Wharf (then only a few months old) written by artist David Critchley who was a member of this artist-committee-run studio-complex situated beside the river Thames. Reflecting the experimental focus of Readings, Critchley describes how the committee that ran that space "decided to invert the prevailing emphasis by which forms of art work are given precedence, and gave priority to time durational work like music, expanded cinema, video and live performance." ${ }^{3}$ Similarly, the reviews in Readings document radical reinventions of sound, music, performance-a politics physically rooted to space and place. Places such as $2 \mathrm{~B}$ Butlers Wharf, a location removed from the contexts of production co-habiting at Gloucester Avenue, reveal how crossover practices encompassed a wider geographical map. Artists in this context actively "inverted" not only preconceived ideas, but also the spaces such artworks inhabited physically and critically.

The first issue of Readings begins with a statement "On Readings" in which Nicolson observes that the "emphasis of much contemporary work is on the perception of the event. Constant vigilance to the nature of one's responses is encouraged, particularly in relation to work that manifests within its own structural duration in time. ${ }^{32}$ In this statement she undertakes a self-conscious re-application

\footnotetext{
${ }^{29}$ Gerry Gold, “Discussion Document: Music in Transition,” LMC Archive, early I970s.

30 Readings, no. 2, April 1977, front cover.

${ }^{31}$ David Critchley, "2B Butlers Wharf," Readings, no. I, 1977, p. I3.

${ }^{32}$ Annabel Nicolson, “On Readings,” Readings, no. I, February 1977, p. I.
} 
of what was then a loaded term-structuralism. 33 Structuralist filmmaking in the UK sought to foreground and redefine the conventions associated with viewing and interpreting cinema. Structuralist filmmakers reduced, dissected, and abstracted the homogenized techniques of mainstream cinema-narrative, sound, image, composition-but they also multiplied books and writings about these approaches. As Malcolm Le Grice observes, filmmakers at that time "paid increasing attentions to the actuality of their materials and processes." 34 Writing was a way of extending the audiences of performances and screenings, which were usually witnessed by only a handful of people.

Within the Film Co-op, there was a subtle spectrum of application and interpretation when it came to filmic structuralism. From the theorized "antinarrative" techniques of Peter Gidal, who also edited the Structural Film Anthology 35 in 1976, to the differing politicized "anti-illusion” of Le Grice, who also created Filmaktions with Nicolson, structuralist discourses about the "materiality" of film manifested as "expanded cinema" and as film works, texts, and criticism. Nicolson and other Filmaktion performers used the light-beam, the mechanics of the projector, and the grain of the film strip to create artworks. As it was published in 1977, shortly after these books, all three issues of Readings sit alongside these now canonical writings. However, Readings was markedly different in its focus upon "structural" duration in time and emphasis on perceptions of/after the event, beyond specific media.

Katherine Hayles observes that media-specific analyses can involve a "defamiliarization" as writing fails "to account for all the other signifying components of electronic texts, including sound, animation, motion, video, [and] kinaesthetic involvement." ${ }_{36}$ This defamiliarization connects to Readings' overall project-the documenting of perception of performances. Musician and filmmaker Rob Gawthrop observes a sensory prioritization and defamiliarization:

The structural approach to film has tended to be theorised in relation to language, the visual and the problematic of representation. Much work that

33 UK "structuralism" was different to that associated with American practitioners described in P. Adams Sitney, Visionary Film: The American Avant-Garde, New York, Oxford University Press, 1974-1979.

34 Malcolm Le Grice, Abstract Film and Beyond, London, Studio Vista, 1977, p. 152.

35 Peter Gidal (ed.), Structural Film Anthology, London, British Film Institute, 1976.

${ }^{36}$ Katherine Hayles, Writing Machines, Cambridge, Massachusetts, MIT, 2002, p. 20. 
was frequently lumped within this structuralist film bracket was artistically affirmative and not dependent upon such a reductionist anti-narrative polemic. The context of event and the consequent immediacy of the viewing/listening experience were central to the meaning of such work. Sound (noise) and image relations were integral. Sound was not an applied soundtrack used as a comforting adjunct to the visual explorations, it was integral. ${ }^{37}$

Sounded dynamics were central not only to wider structuralist practices at that moment, but also to the event-based practices discussed in Readings and pursued by artists such as Gawthrop, whose work is also reviewed in the first issue of Readings. ${ }^{38}$

\section{SOUND (IN) SPACE}

Critchley's short history of $2 \mathrm{~B}$ Butlers Wharf is preceded in Readings no. I by a review of a sound performance by artist Stuart Marshall, which took place at this venue on Saturday, December I8, 1976. 39 Originally advertised as Idiophonics (meaning "ideas through sound") the title was changed on the night of the performance to Heterophonics ("a multiplicity of sounds in space"). ${ }^{\circ}$ Written by David Toop, who was a founding member of the LMC (until 198I), this text documents a unique moment in Marshall's career, preceding his work as a documentary filmmaker and as a gay rights activist for which he is better known today..$^{4}$ Toop and Marshall were friends who had met at Hornsey College of Art in

${ }^{37}$ Rob Gawthrop, "Film Noise Aesthetics," in Jackie Hatfield (ed.), Experimental Film and Video: An Anthology, Eastleigh, John Libbey Publishing, 2006, p. 57.

${ }^{8}$ T. Sinden, "Rob Gawthrop: Film Co-op, 2.2.77," Readings, no. I, February 1977, p. 6.

39 David Toop, “'Heterophonics' by Stuart Marshal," Readings, no. I, 1977, p.3-4. http://www.nicolascollins.com/texts/toop_heterophonics.pdf (accessed 4 January 2or8).

$4^{\circ}$ Ibid., p. 3. In another article, Toop confused the meaning of "ideo-" with "idio-", David Toop, "Sound Thinking: Stuart Marshall's Idiophonics," Davidtoop, Io July 20I3, https://davidtoopblog.com/2013/07/Io/sound-thinking-stuart-marshalls-idiophonics/ (accessed 5 January 2018).

${ }^{41}$ Stuart Marshall, Bright Eyes, 1986, http://www.vdb.org/titles/bright-eyes (accessed 4 January 20I8). Marshall was influential in developing the UK/Canada video exchange during the I970s-8os. See Conal McStravick, "\#I: Learning in a Public Medium: Stuart Marshall's Sound Works Part I - Hornsey, Newport, Wesleyan, Newcastle (1968-1978)," LUX London, 2 December 20I5, https://lux.org.uk/writing/conal-mcstravick--learning-in-a-public- 
1967. The article provides insights into Marshall's background, for instance his studies in the US under the composer Alvin Lucier and his intellectual influences, among whom is the "radical semiologist" Julia Kristeva. In many ways personifying the social intersections that converge in Readings' pages, Marshall was a pioneer of early video art and he wrote seminal essays on this new art form. Earlier in 1976 he cofounded London Video Arts ${ }^{2}$ and attended the meeting of the National Musician's Collective where the decision to form the LMC was made. Marshall's "laissez-faire [and] downright versatile approach to media" addressed topics that were "taboo in almost all current contemporary music." 43

Marshall used sound to re-attune the audience's relationship to time and place, an expansion of perception initiated by the aural, as opposed to the visual, and shared by other artists who contributed to Readings. Heterophonics involved three performers-Marshall alongside artists Nicolas Collins and Jane Harrisson-who stood back-to-back in "the centre of the large, empty space. Each of them had one wood block —each block of a different but close pitch—and one hard beater." 44 They paced away from one another "radiating out from the central point towards the corners," then each took an aerosol klaxon and the "large wooden doors of $2 \mathrm{~B}$ were thrown open to let in the freezing night." 45 Having climbed down to the bank of the Thames, the performers moved at intervals, whilst the audience listened to "the sound of these horns braying out over the river." ${ }^{46}$ In this description Toop records details about an otherwise undocumented performance, including the audiences' reactions to it and their movement in that space. He describes how they watched for a while from the "precarious platforms" that jutted out from the windows of Butlers Wharf, before coming inside and huddling around an electric fire, at which point the performance took on the "dimensions of a social gathering punctuated by alternately mournful and strident honking from outside." 47

\footnotetext{
medium-stuart-marshalls-sound-works-part-I-hornsey-newport-wesleyan-newcastle-19681978 (accessed 4 January 2018).

${ }^{42}$ London Video Arts (later London Video Access/London Electronic Arts) merged with the London Film Co-op in the late 1990 os to form The Lux Centre, which folded in the early 200os, when a new organization was formed, the distributor LUX, London.

43 Toop, 1977, p. 3.

44 Ibid.

45 Ibid.

${ }^{4}$ Ibid.

47 Ibid.
} 
The immediacy and importance of this setting reflects Nicolson's statement in "On Readings" in which she encourages constant "vigilance to the nature of one's responses." ${ }^{8} 8$ Exemplifying this continued vigilance, Toop revisited this 1977 review when Marshall's Idiophonics composition was re-performed in 2013. ${ }^{49}$ Further insights and clarifications are added to this later text, along with observations by musician Gavin Bryars and artist/composer David Cunningham who were also present at the 1976 recital. These personal reflections are affected by the fact that Marshall passed away in 1993 and as Toop reiterates, the fact that nothing "of the event could be conveyed through secondary media-you had to be there." ${ }^{\circ}$ Yet this re-visitation reveals that texts can instigate further readings as the process of rereading (and re-performing) triggers yet more responses at later dates.

\section{READINGS AS “METADISCOURSE”}

$I_{17}$ The collaborative and solo works made by Nicolson and Burwell involved what Catherine Russell terms an "autoethnographic" inscription of self that complicates the study of their parallel writing and editorial work on Readings:

Autobiography becomes ethnographic at the point where the film- or videomaker understands his or her personal history to be implicated in larger social formations and historical processes. Identity is no longer a transcendental or essential self that is revealed, but a "staging of subjectivity" - a representation of the self as performance..$^{51}$

Burwell and Nicolson not only questioned representation by the staging of the self, but by writing about the works of others in a public forum (albeit one with a small circulation), they and other contributors to Readings are implicated in larger social formations and historical processes. Formations that texts and works from this period sought to redefine.

${ }^{48}$ Nicolson, 1977, p. I.

49 David Toop, Rie Nakajima, Angharad Davies, Lina Lapelyte, Daniela Cascella, Idiophonics, performance, Café Oto Project Space, London, II July 2013.

so David Toop, 20I3.

${ }^{51}$ Catherine Russell, Experimental Ethnography: The Work of Film in the Age of Video, London, Duke University Press, 1999, p. 276. 
Burwell passed away in 2007..$^{22}$ Though it is no longer possible to ask him about these works, it is possible to revisit these practices in his books and in other written accounts. Further to editing Readings he ran his own publishing company, Mirliton, and wrote/published several books on music in the 1970s. 53 Burwell's percussive improvised performances used complex sculptural sets, space, and sound to redefine environments as conductors of resonance and meaning (see Fig. 5). The installation The Museum of Illegal Medicine, as described by Nicolson in Readings no. I, was an "exploratory acoustic environment" with projections of river, sea, and clouds that connected to the wider setting surrounding $2 \mathrm{~B}$ Butlers Wharf where the environment was installed. 54 Large objects were hung from piano strings, wires that "needed to be plucked, ribbed, struck or bowed to set up resonances in the objects, often at some distance from the person initiating the vibrations." ss Such participations provoked "a travelling network of sound" and "spatial disorientation" in the audience. ${ }^{66}$ Another review from this time in Melody Maker describes Burwell as a "space explorer" 57 - roaming through, adapting, and performing in this space (with Toop) during its week-long display. This was, to use Burwell's own words, "the art of creating forms in four dimensions, revealing the nature of materials in sound, the visible aspects of which constitute the lesser part of the work." ${ }^{8}$ As Nicolson writes, this "acoustic environment was less a situation for phaneric signs of functional amplification and more a project for improvised discovery." 59

Chris Stover explores the embodied "materiality" of improvised performances, observing how this type of enactment differs from reciting a composed or pre-written piece. He identifies intermedial spaces "between the bodies of human performers, between performers and active listeners, between the sonic 'bodies' that comprise the multiple overlapping events that constitute a musical performance's

52 David Toop, "Obituary: Paul Burwell," The Guardian, 5 March 2007, http://www.theguardian.com/news/2007/mar/o5/guardianobituaries.obituaries (accessed 4 January 20I8).

53 Other books by Burwell include Paths into the Forest (London, Writers' Forum, 1973) and Suttle Sculpture (Mirliton, 1974).

${ }_{54}$ Annabel Nicolson, "The Museum of Illegal Medicine," $2 B$ Butler's Wharf, 6-9 December 1976, Readings, no. I, February 1977, p. II.

55 Ibid.

${ }^{56} \mathrm{Ibid}$.

57 Ibid.

${ }^{8}$ Burwell, 1974, p. I.

${ }^{9}$ Nicolson, 1977, p. II. 
unfolding." 60 This is an embodied materiality that occurs during a particular timeframe, bringing "duration" and awareness of physical space to the fore. Improvisation involves bringing different perspectives and language to traditional discussions of music, which according to Stover, tend to consider "music's sonic materialities (the sensible; what can be heard) or the cultural resonances that locate in and through music (the political or hermeneutic; how meaning is inscribed in and for a listening subject)." "II Improvised performances involve a critical duality whereby both the performer and audience inscribe meaning through shared time.

Stover's analysis of improvisation also chimes with Nicolson's statement "On Readings":

attention to perceptual responses as the tools with which one must work to apprehend a situation inseparable from the recognition that meaningful activity does not end with the intentions of the artist but is further constructed by the perceptual tuning of those who come across the work. Where the activity of the artist and the public experience of it are simultaneous these concerns are of added relevance. ${ }^{62}$

Readings collates audience accounts of performances- "audiences" that were often comprised of other artists, as when Nicolson reviews Burwell or Toop reviews Marshall. It captures the shared experiences of audience members who were also coproducers of the works they saw and heard.

Nicolson's performances often explored the materiality and/or the nonmateriality of filmic time. Reel Time (1973) took place in her studio at the Dairy where the Film Co-op was based before moving to Gloucester Avenue. The performance involved Nicolson sewing a long loop of film, which passed continuously through a sewing machine, the audience, and a projector at the back of the space. As the film started to deteriorate the holes and tears became increasingly visible in the filmed image (which depicted Nicolson sewing) and the loop had to be repaired frequently by the projectionist. At the same time the light from a second projector (with no film in it) threw a shadow of her sewing in real time onto another screen. Occasionally, two volunteers from the audience would read aloud-one from a manual on how to

60 Chris Stover, "Musical Bodies: Corporeality, Emergent Subjectivity, and Improvisational Spaces," M/C: A Journal of Media and Culture, vol. I9, no. I, 2016.

61 Ibid.

${ }^{62}$ Nicolson, 1977, p. I. 
thread the sewing machine, the other from a manual on how to thread the projector-their voices more evident in pauses while the loop was being repaired. It lasted until the film loop was beyond repair and could no longer pass through the projector.

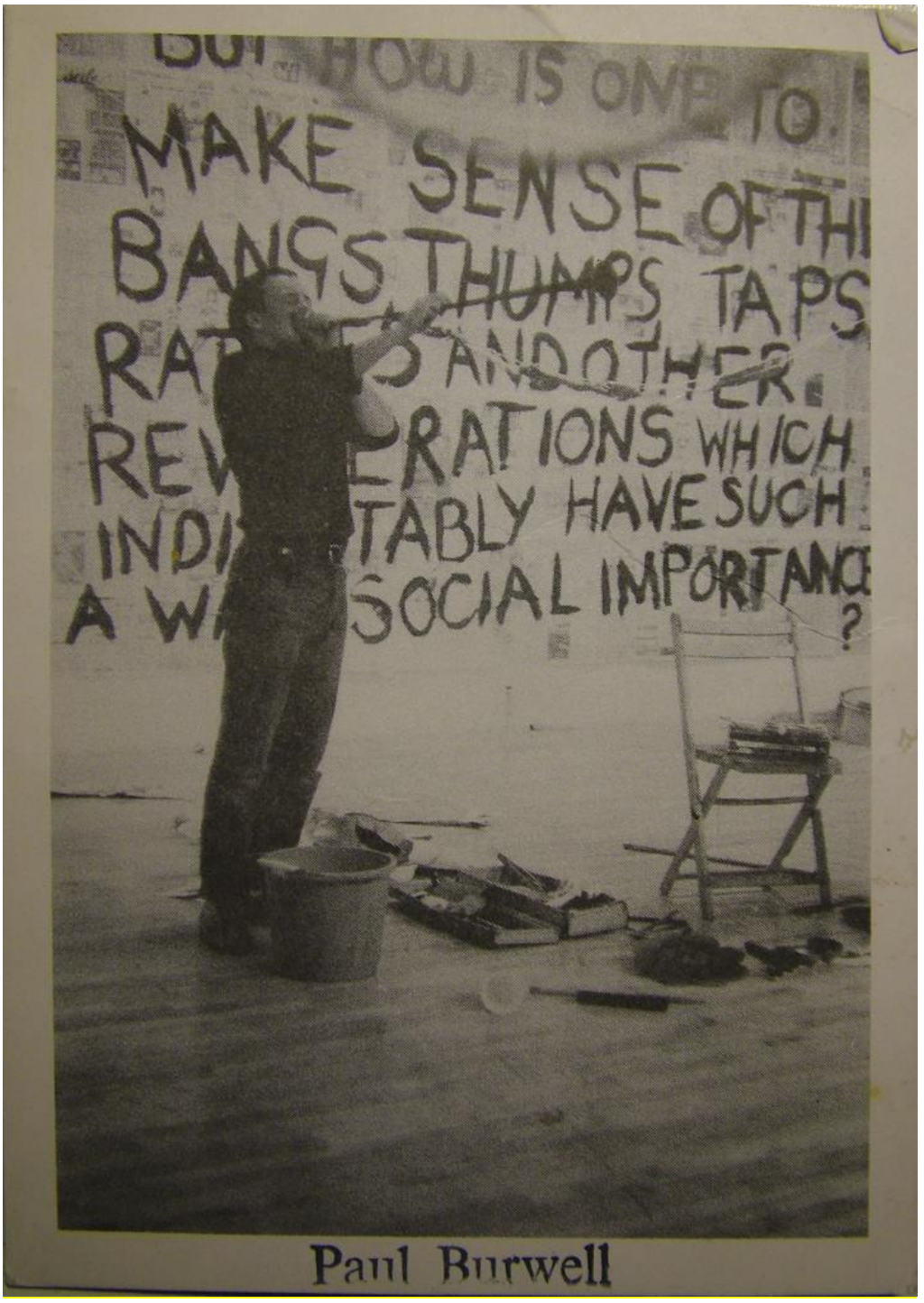

Fig. 5. Paul Burwell performing c.I970s. Photo @ Paul Burwell Archives. Published with the permission of Anne Bean. 
Even though it is regularly cited as a key work of this time, there is little documentation of Reel Time, with only a few photos attesting to its appearance and duration. Over the years, inconsistencies have crept into accounts as one researcher reads and cites another. ${ }^{63}$ Nicolson did not record her performances and texts about them are absent from the pages of Readings (though earlier works made in collaboration with Burwell are mentioned briefly in her review of The Museum of Illegal Medicine). When considering this afterlife, it is pertinent to return to Nicolson's statement at the start of Readings no. I:

If attitudes of attention are under revision then the distinctions between artist and audience and the boundaries around a "work" (i.e. the situation in focus) are also wavering. Qualities of attention can illuminate an existing or spontaneous situation. An appreciation of phenomena, of the moment, of circumstances, brings into focus external events not designed to be framed. Many artists prefer their work to be stumbled across, happened upon or approached unwittingly. Ideas of risk, of work being subject to external vagaries beyond the artists' control are part of a willingness to let events occur without predicting their course or predefining their boundaries. ${ }^{64}$

Works were "not designed to be framed" and their boundaries constantly shift, as do accounts of Reel Time. Beyond the time-based experience of such works, perception of them in writing triggers further readings. Origin works-and artists such as Nicolson-are resistant to absolute definitions of these boundaries, and histories often garner a definitive positioning that is antithetical to their mutable, original, and/or ongoing nature.

In exhibitions and surveys of this recent history, rather than re-enact her works or show filmed documentation (of which there is little), Nicolson has opted to display her writings, enacting a critical re-visitation rooted in the fact that textual documents are also physical artefacts. ${ }^{65}$ Handwritten texts have been reprinted in

${ }_{63}$ The account of Reel Time (1973) included here closely follows that described by Annabel Nicolson in a letter to Claire M. Holdsworth, I8 February 2018.

64 Ibid.

65 Texts written by Nicolson were displayed at: Film in Space: An Exbibition of Film and Expanded Cinema, Camden Arts Centre, London, Is December 2012-24 February 2013, selected by Guy Sherwin, http://www.camdenartscentre.org/whats-on/view/exh-25 (accessed 4 January 20I8); Field Work: Film, Sound and Voice, programmed by Lucy Reynolds in 
books as well as displayed on gallery walls, performance "scores" and letters to the present from a now unknowable, half-remembered past. Some of these texts adopt an embodied personal narrative, which is exemplified by the title of Nicolson's 1994 text/work, "I was sitting with my back to them, sewing, a beam of light coming at me from the projector." 66 As Russell observes, by "inscribing themselves on the level of 'metadiscourse' film and video makers also identify with their technologies of representation, with a culture of independent filmmaking, alongside their other discursive identities." 67 Though not strictly concerned with Burwell and Nicolson's works, Readings extends interpretation of their complex relationships with writing as well as with performance, sound, and space.

\section{CONCLUSION-AT THE INTERSECTION (COUNTERPOINT HISTORIES)}

Paper may be of longer duration than performance, trees longer still, stones yet longer but ultimately all are on the same track. We have no option but to listen. ${ }^{68}$

Readings is symptomatic of a wider turn towards writing as part of and as an extension of multidisciplinary artistic practices in the 1970s. As transitions in technology and medium were documented on the pages of this and other artist-run magazines at that time, so too was the nature and function of criticism and writing (as another technology of representation) subject to this redefinition. The densely filled black-and-white pages of Readings trace contour lines akin to those on a map, tracing connections and indicating differences over a complex landscape, describing unseen, unsounded terrains. This short-lived magazine indicates complex interdisciplinary collaborations, spaces, artworks, and this article has explored the historical potentials of such print-fora by considering critical writings as sites of productive and discursive intermedial convergence.

association with CHELSEA space, CCW in partnership with the ICA, London, 4 March 20I7; "FILMAKTION: Expanded Cinema and Film Performance," at Raven Row Gallery, London, curated by Mark Webber as part of the exhibition This Way Out of England: Gallery House in Retrospect (seven weekends of performances, screenings and discussions), 4-5 March 2017, https://lux.org.uk/event/filmaktion-raven-row-march-20I7 (accessed 4 January 2018).

${ }^{66}$ Nicolson, "I was sitting with my back to them, sewing, a beam of light coming at me from the projector," 2011 , p. 158.

${ }^{67}$ Russell, 1999, p. 278.

${ }^{68}$ Nicolson, 1977, p. I. 
Accounts of the complex social geographies of the LMC and the Film Co-op do not straightforwardly correspond to delineated artistic fields, occupations nor titles. Tracing this multifaceted history involves negotiating subjective interpretations and lived histories, which involve members whose memories vary. As with all complex organizations that have gone through several phases-demarked by transitions in staff and location amongst other factors-there is more to be said about this collective and co-operative well as the people who used these facilities. There were strained moments within each organization internally, along with disagreements during this co-habitation, when amenities (such as the shared telephone line and bathroom facilities) at 42 Gloucester Avenue were stretched. Archival texts provide a means of prompting and focussing personal reflections about this history. ${ }^{6}$ Archivist and curator Andrea Zarza Canova, who catalogued the LMC archive, has observed that oral historical projects supplement and act as a counterpart to such archives, precisely because paper documents contrast with the sounded subjectmatter and egalitarian organizational structures to which they refer. ${ }^{70}$

As an archival artefact, Readings carries a snapshot of this context into the future. Critical artefacts such as this inhabit intermedial spaces that bridge the gap between then and now, whilst also documenting rare overlaps between otherwise separate organizations. The texts, performance diagrams, and images in Readings remediate unique typographies, indicating ecologies that might be otherwise forgotten due to the invisibility of works and the audience responses they record. Nicolson's vigilant system of attentive re-tuning and "response" applies to the reinscription of Readings within histories and accounts such as this and the potentials for reframing traditionally loaded language and terms (such as structuralism). These autoethnographic sources, unlike the origin events they describe, can be reread over and again, reactivating the metadiscursive agency of makers and spectators as cocreators. $^{7 \mathrm{I}}$

${ }_{69}$ As used by Andrea Zarza Canova and David Toop, who completed an AHRC-funded oral history/interview-based project on the LMC, 20I7, Archives and Special Collections Centre, LCC, UAL.

70 Andrea Zarza Canova, "PoL \# 39 Improvise, because you're not a record! An introduction to the London Musicians' Collective archive," Points of Listening, CRiSAP, LCC (UAL), 23 February 2018, https://pointsoflistening.wordpress.com/2018/or/29/pol-39improvise-because-youre-not-a-record-an-introduction-to-the-london-musicians-collectivearchive/ (accessed 24 February 20I8).

${ }^{71}$ Lucy Reynolds, "Controlling Agent: Artist and Spectator in the Film Actions of Gill Eatherley and Annabel Nicolson,” in François Bovier and Adeena Mey (eds.), Cinéma 
Comparative exploration of the reviews in Readings reveals that the relationship between the LMC and the Film Co-op was not merely a coincidental geographical convergence borne of necessity. In a few rare and fleeting instances this co-habitation facilitated cross-pollination. Works used sound to physically inhabit politicized spaces, rendering an alternative mapping of time and place (as well as that space) through perception of the live-event. As a technology of representation, text was a means of extending the reach of ephemeral sound-based performances. To use Nicolson's words, by “recognising the vulnerability of events in time one fosters a more resonant response to objects. Equally susceptible to changes of meaning and matter they can be seen as passengers along the same time scale as events." ${ }^{22}$ Texts not only absorb this resonance, they store and channel artworks and practices as an important and key part of multidisciplinary artistic practice. Referring to critical texts and not solely relying on secondary accounts, which can at times be misleading, is a way of reiterating the embodied nature of these "expanded" practices, and a way of reasserting that sound was fundamental in repositioning a metadiscursive criticality that was connected to physical environment, space, and place ${ }^{73}$.

exposé - films d'artistes, art video et exposition d'images en movement / Exhibited cinema exbibiting artists' films, video art and moving image, Dijon, École cantonale d'art de Lausanne/Les presses du réel, 2015 .

${ }^{72}$ Nicolson, 1977, p. I.

${ }^{73}$ For more information about London Film-Makers' Co-op mixed programme, see:

https://player.bfi.org.uk/free/collection/london-film-makers-co-op (accessed Io June 2018). 


\title{
Readings at the Intersection: Social Ecologies in Critical Texts
}

\author{
Claire M. HOLDSWORTH, KingSTON SCHOOL OF ART, KingSTON \\ UNIVERSITY LONDON
}

\section{ABSTRACT}

Taking extracts from Readings, a short-lived reviews magazine edited by artists Annabel Nicolson and Paul Burwell in 1977, this article explores the intersection between two collectively organized artist-led groups-the London Musicians' Collective and the London Film-makers' Co-operative, which were based at the same address between 1977 and 1988. It considers how texts, as extensions of artistic practices, garnered innovative performance criticism and cultures in London at that time. Magazines such as this are posited as a productive means of mapping complex social ecologies and histories involving multiple disciplines.

\section{RÉSUMÉ}

À partir d'extraits de compte-rendus de la revue éphémère Readings qu'ont éditée les artistes Annabel Nicolson et Paul Burwell en 1977, cet article examine le lien entre les collectifs d'artistes The London Musicians' Collective et la London Film-makers' Cooperative, tous deux basés à la même adresse entre 1977 et 1988. Il s'agit de montrer la façon dont les textes, en tant qu'ils prolongent les pratiques artistiques, engrangent une pensée critique de la performance, mais également différentes cultures contemporaines. Des revues comme Readings fournissent des outils idoines pour cartographier la complexité des écologies sociales et les croisements entre les disciplines.

\section{NOTE BIOGRAPHIQUE}

DR. Claire M. HoldswORTH is an archivist and researcher specializing in British art and moving image and she is also Early Career Research Fellow at Kingston School of Art (Kingston University London). Her current research explores the connections between experimental sound and film/video in London during the 1970s and the 1980s. She has published writings in the Moving Image Review and Art Journal (MIRAJ), in Vertigo magazine, and in other publications. She has worked on exhibitions and co-curated screening programmes, most recently, Towards Other Cinemas (with Laura Mulvey and Sue Clayton) at the Whitechapel Gallery (London, 2017). 